\title{
Sir George Montario Bedbrook: a tribute
}

\author{
G M Pool MD \\ Oostdijkseweg 14A, 3252 LN, Goedereede, Netherlands
}

At the meeting in Holland in 1980, the first meeting of our Society after the death of Sir Ludwig Guttmann, it became known that Sir George Bedbrook from Australia had agreed to become president elect to follow Professor Volkmar Paeslek from Germany. Dr Ellis Griffiths wrote a profile on Sir George stating that his election would ensure that the International Medical Society of Paraplegia would continue to develop as the internationally recognised forum for clinicians throughout the world. At the Royal College of Physicians of London, Sir George gave the first Sir Ludwig Guttmann Lecture entitled 'Ludwig Guttmann-Man of an Age' and stated what Sir Ludwig has meant to the lands of the Southern Cross. As the first president of the post Guttmann era Sir George showed the way through difficult waters and did this in an outstanding way by organising and reorganising, making the Society stronger and more internationally minded.

The last meeting Sir George presided over was the one in Denver USA in 1984; and subsequently there was a large attendance at the first meeting ever held in the southern hemisphere, in Perth, on the occasion of the Australian bicentenial. At that occasion I had the opportunity to present a pewter plate to Sir George in remembrance of Dirk Hartog and his crew, who were the first to arrive on the west coast of Australia, on 25 October 1616. I had hoped to visit him and see the plate, and Sir George answered my letter immediately telling me that it was just possible that at the beginning of October he might be out of town. His letter ended with 'Warmest wishes, Yours sincerely, George'. I have the feeling that those wishes were a last salute to all members of the Society! At the thanksgiving service for George Montario Bedbrook at the cathedral church of St George, situated at the board of St Georges Terrace in Perth, I had the honour of sitting next to my fellow vice president of those days, Ellis Griffiths; many important people were present.

In many of his publications, and also in his book 'The Care and Management of Spinal Cord Injuries', Sir George had a message. The one which impressed me most was from 1966: 'Adequate clinical judgment in medicine needs physicians who have a knowledge of morbid pathology, morbid physiology and human understanding. These basic concepts of medicine can now be applied to the management of spinal cord trauma'.

At the thanksgiving service Sir George's eldest son David also gave us a message, that he as a son of his famous dad had decided to find his own way. I think we all have to do that now. 